DOI: https://doi.org/10.33507/cakrawala.v5i1.223

\title{
Manajemen Strategi Hubungan Masyarakat dalam Meningkatkan Minat Calon Siswa Bersekolah di Yayasan Surban MTs Pacet Mojokerto
}

\author{
Mika Julianti \\ Institut Pasantren KH. Abdul Chalim \\ mikajulianti33@gmail.com
}

\begin{abstract}
The main objective of carrying out a public relations strategy management in an educational institution is that the school continues to be in demand by educated participants and experiences development and progress from year to year. In conveying information, good communication is needed so that the information submitted can be received. In conveying information, public relations must have good strategic management and direction so that what is expected is carried out well. Data collection techniques are carried out by observation, interviews and documentation. The results of this study indicate that: (1) Public Relations Strategy Management in Increasing Student Interest in MTs Pacet Surban Foundation includes planning, communicating, implementing and evaluating well and directed by the school to attract the attention of prospective new students. (2) One of the inhibiting factors for public relations in increasing the interest of prospective students to attend the MTs Pacet Surban Foundation includes ineffective time in the implementation of management as well as long distances so that strategic management is not optimal.
\end{abstract}

Keywords: Strategic Management, Public Relations and Student Interest

\begin{abstract}
Abstrak
Tujuan utama dilakukannya manajemen strategi hubungan masyarakat dalam sebuah lembaga pendidikan ialah agar sekolah tersebut terus diminati oleh peserta didik dan mengalami perkembang serta kemajuan dari tahun ketahun. Dalam menyampaikan informasi diperlukan komunikasi yang baik agar informasi yang disampaikan dapat diterima. Dalam menyampaikan informasi humas harus memiliki manajemen strategi yang baik dan terarah agar apa yang diharapkan dapat terlaksana dengan baik. Teknik pengumpulan data dilakukan dengan observasi, wawancara dan dokumentasi. Hasil penelitian ini menunjukkan bahwa: (1) Manajemen Strategi Humas dalam Meningkatkan Minat Siswa Bersekolah di Yayasan Surban MTs Pacet meliputi perencanaan, pengkomunikasian, pelaksanaan dan pengevaluasian dengan baik dan terarah yang dilakukan oleh pihak sekolah untuk menarik perhatian calon peserta didik baru. (2) Salah satu faktor penghambat humas dalam meningkatkan minat
\end{abstract}


calon siswa bersekolah di Yayasan Surban MTs Pacet meliputi waktu yang kurang efektif dalam pelaksanaan manajemen serta jarak lokasi yang jauh sehingga manajemen strategi yang dilakukan kurang maksimal.

Kata Kunci: Manajemen Strategi, Hubungan Masyarakat dan Minat Siswa

\section{PENDAHULUAN}

Pendidikan Nasional merupakan pendidikan yang berakar pada nilai-nilai agama, kebudayaan Nasional Indonesia, dan tanggap terhadap perubahan zaman berdasarkan pada Pancasila dan UUD 1945. Pendidikan merupakan proses untuk meningkatkan, memperbaiki, serta mencetak manusia untuk selalu mengembangkan keterampilan melalui proses pengajaran dan pelatihan. Sekolah merupakan lembaga pendidikan formal yang diarahkan untuk meningkatkan mutu pendidikan. Seluruh komponen serta perangkat yang ada di dalam suatu lembaga pendidikan diharapakan dapat memuasakan peserta didik dalam menuntut ilmu pengetahuan.

Siswa merupakan komponen penting dalam dunia pendidikan selain sarana dan prasarana pendukung pendidikan. Minat siswa merupakan faktor penting sebagai penentu dalam memilih sekolah. Agar sekolah tersebut tetap diminati siswa tentunya diperlukan manajemen strategi dari pihak sekolah.. Pembahasan mengenai humas, pada lembaga pendidikan masih belum difungsikan secara baik. Hal ini karena kurangnya informasi dan pengetahuan yang dimiliki oleh para pengelola atau pelaksana lembaga pendidikan tersebut.

Humas memiliki posisi yang sangat penting dalam sebuah lembaga baik dalam sebuah lembaga organisasi, perusahaan maupun lembaga- lembaga lainnya seperti sekolah. tujuan humas ialah untuk menyebarkan informasi, menciptakan, memelihara, dan membina hubungan baik kepada masyarakat sehingga terjalin hubungan yang harmonis dan mendapat citra yang positif bagi sekolah dan masyarakat. Manajemen strategi humas harus terarah dan terencana dengan sebaikbaiknya.

Berdasarkan studi pendahuluan yang dilakukan oleh peneliti terhadap informasi terkait manajemen strategi humas. Hasil wawancara pada saat peneliti melakukan observasi kepada salah satu narasumber yang merupakan kepala sekolah 
menunjukan bahwa terbantuknya humas di sekolah sebagai alat untuk menyampaikan informasi kepada calon peserta didik dan masyarakat sekitar.

Berdasarkan asumsi yang peneliti temukan bahwa Yayasan Surban MTs Pacet belum membentuk struktur kehumasan dengan baik, hal ini ditunjukan dengan rendahnya minat peserta didik yang ditandai dengan adanya penurunan jumlah peserta didik dari tahun ketahun. Selain rendahnya minat calon peserta didik, humas di sekolah Yayasan Surban MTs Pacet juga belum terarah dan difungsikan dengan baik sesuai dengan fungsinya yaitu menarik minat calon peserta didik.

Penelitian yang dilakukan di Yayasan Surban MTs Pacet ini dilakukan untuk mengetahui bagaimana manajemen strategi hubungan masyarakat dalam meningkatkan minat siswa bersekolah di Yayasan Surban MTs Pacet Mojokerto.

\section{PEMBAHASAN}

\section{Manajemen Strategi}

Defenisi manajemen strategi menurut Barney mengartikan sebagai proses pemilihan dan penerapan strategi secara keseluruhan mengenai penggunaan sumber daya untuk menciptakan posisi yang menguntungkan. Manajemen strategi adalah seni dan ilmu penyusunan, penerapan, dan pengevalusian keputusan lintas fungsional yang memungkinkan suatu perusahaan mencapai sasarannya, mengembangkan kebijakan dan perencanaan untuk mencapai sasaran, serta pengalokasian sumber daya untuk menerapkan kebijakan dan perencanaan pencapaian tujuan organisasi. ${ }^{1}$

Manajemen strategi terdiri atas tiga proses meliputi:

1) Pembuatan strategi, meliputi pengembangan misi dan tujuan jangka panjang, mengidentifikasi peluang dan ancaman dari luar serta kekuatan dan kelemahan lembaga pendidikan.

2) Penerapan strategi meliputi, penentuan sasaran operasional tahunan, kebijakan organisasi, pemotivasian anggota dan pengalokasian sumber daya.

3) Evaluasi/control strategi, mencangkup usaha-usaha untuk memotivator seluruh pembuatan dan penerapan strategi termasuk mengukur kinerja individu dan perusahaan serta mengambil langkah-langkah perbaikan.

\footnotetext{
${ }^{1}$ Rachmad, Manajemen Strategik, (Bandung: CV Pustaka Setia, 2014), 8
} 
Tujuan dari manajemen strategi adalah melaksanakan dan mengevalusi strategi yang dipilih secara efektif dan efisien, mengevaluasi kinerja, merumuskan pengembangan lingkungan eksternal, meninjau kembali kekuatan, kelemahan, peluang dan ancaman, dan melakukan inovasi atas produk sesuai dengan yang diinginkan.

A. Manajemen Strategi Hubungan Masyarakat

Humas adalah sebuah seni sekaligus ilmu sosial dalam menganalisa kecenderungan, meramalkan konsekuensinya, memberikan pengarahan kepada pimpinan institusi/lembaga dan melaksanakan program-program terencana yang dapat memenuhi kepentingan baik institusi lembaga tersebut maupun masyarakat yang terkait. ${ }^{2}$

Humas bertanggung jawab untuk memberikan informasi, mendidik, meyakinkan, meraih simpati, dan membangkitkan ketertarikan masyarakat akan sesuatu atau membuat masyarakat mengerti dan menerima sebuah situasi. ${ }^{3}$

Permendiknas No. 24 Tahun 2008 tentang Standar Tenaga Admnistrasi Sekolah/Madrasah, Tugas Pelaksanaan Administrasi Hubungan Sekolah dengan Masyarakat yaitu: ${ }^{4}$ (a) Mengatur hubungan sekolah dengan orang tua, Memelihara hubungan baik dan memfasilitasi kelancaran kegiatan dengan komite sekolah, (c) Membantu merencanakan program keterlibatan stakeholders, (d) Membina kerjasama dengan Pemerintah dan lembaga-lembaga masyarakat, (e) Mempromosikan sekolah/madsarah, (f) Mengkoordinasikan penelusuran lulusan (alumni), g) Melayani tamu sekolah/ madrasah, (h) Membuat layanan sistem informasi dan pelaporan hubungan sekolah dengan masyarakat, (i) Memanfaatkan TIK untuk mengadministrasikan hubungan sekolah dengan masyarakat, (j) Memberi pengertian kepada masyarakat tentang fungsi sekolah melalui bermacam-macam tehnik komunikasi (majalah, surat kabar dan mendatangkan sumber).

Tujuan utama Public Relation diatas sebagai berikut: (a) Mengevaluasi sikap dan opini public, (b) Formulasi dan implementasi prosedur organisasi atas

\footnotetext{
${ }^{2}$ Abdul Rahmad, Manajemen Humas Sekolah, (Yogyakarta: Media Akademi, 2016), 11.

${ }^{3}$ Rachmadi, Public Relations, (Jakarta: PT Gramedia Pustaka Utama, 1996), 1.

${ }^{4}$ Uraian Tugas Pokok Tenaga Administrasi (Berdasarkan Permen Diknas RI No. 24 Tahun 2008 Tentang Standart Tenaga Adminstrasi Sekolah).
} 
komunikasi organisasi/perusahaan dengan publik, (c) Mengkoordinasikan programprogram komunikasi, (d) Mengembangkan hubungan komunikasi dua arah mengembangkan hubungan positif antar organisasi dan publik. ${ }^{5}$

Dalam manajemen sistem pengelolaan tidak akan berhasil jika tidak dilaksanakan dengan menggunakan strategi yang sesuai, strategi tersebut meliputi: distingtif, fokus, reputasi dan identitas. ${ }^{6}$ Strategi humas yang berfungsi untuk memperkenalkan lembaga kepada masyarakat dan menarik minat masyarakat juga dapat dilakukan dengan kegiatan langsung dan kegiatan tidak langsung. ${ }^{7}$

B. Manajemen Strategi Hubungan Masyarakat dalam Dunia Pendidikan

Defenisi manajemen strategi humas menurut Ruslan, suatu proses dalam menangani perencanaan, pengorganisasian, pengkomunikasian serta pengkoordinasian yang secara serius dan rasional dalam upaya pencapaian tujuan bersama dari organisasi atau lembaga yang diwakilinya. ${ }^{8}$

Defenisi menurut para ahli, Hunger dan Wheelen mendefinisikan manajemen berbasis sekolah strategi adalah seperangkat keputusan dan aksi yang menentukan kinerja panjang organisasi, yang meliputi scaning lingkungan, perumusan strategi (perencanaan strategi), pelaksanaan strategi serta pengendalian dan evaluasi. ${ }^{9}$

Defenisi manajemen strategi hubungan masyarakat yang di kemukakan oleh, Brown \& Mark Manajemen berarti penelitian, perencanaan, pengkomunikasian, pelaksanaan dan pengevaluasian suatu kegiatan komunikasi yang disponsori oleh organisasi, mulai dari pertemuan kelompok kecil hingga berkaitan dengan konferensi press internasional via satelit, dari pembuatan brosur hingga kampanye nasional melalui multimedia, dari pengumuman pelayanan publik hingga menangani kasus

${ }^{5}$ Abdul Rahmad, Manajemen Humas Sekolah, 15.

${ }^{6}$ Rosalina Nurizal Andi, Manajemen Hubungan Masyarakat dalam Menarik Minat Masyarakat di SMK 2 Ponorogo "Tesis”, (Universitas Islam Negeri Maulana Malikibrahim: Malang), 40.

${ }^{7}$ Anwar Yahya, Upaya Sekolah dalam Meningkatkan Animo Siswa Bersekolah di SMK Perkebunan MM 52 Yogyakarta (Tesis), 28.

${ }^{8}$ Ira Nur Harini, "Manajemen Hubungan Masyarakat dalam Upaya Peningkatan Pencitraan Sekolah (Studi Kasus di SMP Al-Hikmah Surabaya)", Jurnal Inspirasi Manajemen Pendidikan, Vol. 4 No. 4, April 2014, 12.

${ }^{9}$ Akdon, Strategic Management For Educational Management (Manajemen Strategic Untuk Manajemen Pendidikan), (Alfabeta: Bandung, 2006), 231. 
manajemen krisis". ${ }^{10}$ Manajemen strategi humas adalah upaya organisasi untuk bisa menyelaraskan dirinya dengan lingkungannya. Dalam mengelola organisasi tidak lagi memadai bila hanya mengandalkan intuisi, termasuk mengandalkan intuisi dalam menyusun siasat bisnis. ${ }^{11}$ Manajemen public relations merupakan penerapan fungsi-fungsi dasar manajemen, public relations berarti melakukan penelitian, perencanaan, pelaksanaan dan evaluasi terhadap kegiatan komunikasi. ${ }^{12}$ Dari hubungan public yang harmonis akan menimbulkan minat siswa. Defenisi minat menurut para ahli, Whiteringte menyatakan minat merupakan kacendrungan seseorang untuk memilih atau melakukan suatu kegiatan tertentu diantara sejumlah kegiatan lainnya. ${ }^{13}$

Defenisi minat menurut, Barbirn merupakan kesadaran seseorang terhadap suatu objek, orang, atau suatu keadaan yang mempunyai hubungan yang penting terhadapnya. Minat merupakan respon sadar yang bernilai suatu makna yang terkandung di dalamnya. ${ }^{14}$ Minat terdiri dari kognitif dan afaktif, aspek kogniktif berupa konsep positif terhadap suatu objek dan berpusat pada manfaat dari objek tertentu. Aspek afaktif nampak dalam rasa suka atau tidak senang dan kepuasan pribadi terhadap objek tertentu. ${ }^{15}$

Minat seseorang terkadang tidak timbul dengan sendirinya, harus ada unsur kebutuhannya. Minat timbul dikarenakan ada beberapa faktor yang mempengaruhinya. Faktor yang mempengaruhi sehingga munculnya minat sesorang antara lain: 1). Dari diri individu sendiri, 2). Lingkungan (internal dan eksternal). ${ }^{16}$ Berdasarkan pangertian di atas, peneliti menyimpulkan minat merupakan sambutan

\footnotetext{
${ }^{10}$ Ira Nur Harini, "Manajemen Hubungan Masyarakat, 14.

${ }^{11}$ Yosal Iriantara, Manajemen Strategis Public Relations, (Jakarta: Ghalia Indonesia, 2004), 7

${ }^{12}$ Yuke Rahmawati, "Manajemen Public Relations Sebagai Alat Etika Komunikasi dalam Bisnis Islam", Salam; Jurnal Filsafat dan Budaya Hukum - 183

13 Lilis Yulianti, Jurnal Walisongo (Faktor-Faktor Yang Mempengaruhi Minat Masyarakat), Volume 19, Nomor 1, Mey 2011, 110

${ }^{14}$ Raminah Barbirin, Teori dan Apresiasi Puisi (Semarang: IKIP Semarang Pres, 1990), 17

15 Ujang Didi Supriyadi, Jurnal Ilmu Pendidikan (Pelaksanaan BOS dan Minat Masyarakat Mengikuti Pendidikan Dasar Gratis. Jilid 7. Nomor 1, Februari 200, 80.

16 Shaleh Abdul Rahman, Muhbibi Abdul Wahab, Psikologi Suatu Pengantar (Dalam Prespektif Islam), (Jakarta: Prenada Media, 2004), 263.
} 
kesadaran atas ketertarikan terhadap suatu objek tertentu baik berupa benda hidup maupun benda mati yang mempunyai suatu nilai tertentu.

\section{METODE PENELITIAN}

Jenis penelitian yang digunakan dalam penelitian ini adalah kualitatif deskriptif, dengan pendekatan studi kasus. penelitian kualitatif ini dibuat secara sistematis, faktual dan akurat mengenai fakta dan sifat populasi atau daerah tertentu. Teknik pengumpulan data dilakukan dengan observasi melalui pengamatan secara langsung terhadap segala hal yang terjadi dilokasi penelitian. Peneliti melakukan observasi dengan cara melakukan pengamatan dan pencatatan terhadap objek penelitian. $^{17}$

Wawancara dilakukan peneliti dengan mengajukan pertanyaan secara langsung kepada responden, dan jawaban-jawaban responden dicatat atau direkam dengan alat perekam. ${ }^{18}$ Informan yang dijadikan sumber informasi untuk mendapatkan data dalam penelitian ini adalah Kepala Sekolah, Waka Kehumasan, Orang Tua dan Siswa. Tehnik dokumentasi peneliti gunakan untuk melengkapi dan mendukung hasil observasi dan wawancara. Dalam aktivitas analisis data, penulis menggunakan model Miles dan Hubberman, yang meliputi data reduction, data display dan conclusion drawing/verification. Dalam Pengecekan keabsahan data peneliti menggunakan teknik triangulasi. triangulasi adalah untuk meningkatkan kepercayaan peneliti, memahami fenomena, mengungkap temuan unik, mengintrogasi teori dan memberi pemahaman yang jelas tentang masalah.

\section{HASIL PENELITIAN DAN PEMBAHASAN}

1. Manajemen Strategi Hubungan Masyarakat

Berdasarkan temuan yang diperoleh dari hasil wawancara beberapa sumber bahwa manajemen strategi hubungan masyarakat dilakukan atas dasar untuk menambah minat calon siswa baru. Kondisi di lapangan menunjukan bahwa teori ini

\footnotetext{
${ }^{17}$ Sugiyono, Metode Penelitian Pendidikan Pendekatan Kualitatif, Kuantitatif dan R\&D, (Bandung: Alfabeta, 2007), 308.

${ }^{18}$ Irawan Soehartono, Metode Penelitian Sosial, (Bandung: Remaja Rosdakarya, 1999), 67.
} 
sejalan dengan teori manajemen strategi hubungan masyarakat yang dikemukakan oleh Brown \& Mark Manajemen berarti penelitian, perencanaan, pengkomunikasian, pelaksanaan dan pengevaluasian suatu kegiatan komunikasi yang disponsori oleh organisasi, mulai dari pertemuan kelompok kecil hingga berkaitan dengan konferensi press internasional via satelit, dari pembuatan brosur hingga kampanye nasional melalui multimedia, dari pengumuman pelayanan publik hingga menangani kasus manajemen krisis.

\section{a. Perencanaan}

Berdasarkan temuan yang diperoleh dari hasil wawancara beberapa sumber bahwa manajemen strategi hubungan masyarakat bahwa perencanaan dilakukan agar terlaksana dan tersusun dengan baik. Kondisi di lapangan menunjukan bahwa teori ini merujuk pada teori yang dikemukakan oleh Monde dan Premeux bahwa perencanaan disusun berbagai visi, misi, tujuan dan sasaran yang pada tingkat awal menggunakan pengambilan keputusan. Dimana kondisi di lapangan perencanaan di mulai dengan rapat agar perencanaan dalam menyusun program rutin kerja, alat dan media apa saja yang dibutuhkan dan siapa saja yang terlibat di dalamnya.

b. Pengkomunikasian

Komunikasi merupakan aktivitas dalam menyampaikan informasi baik berupa pesan, ide serta gagasan dari pihak satu kepada pihak lainnya. Dalam hal ini dimana Humas di MTs Pacet sudah menjalin komunikasi dengan baik pada guru, siswa baik yang ada dilingkup sekolah dan di luar lingkup sekolah. Komunikasi yang dilakukan oleh humas bertujuan agar terjalinnya talisiraturahmi yang baik antara MTs Pacet dan lembaga Sekolah seperti SD dan MI.

c. Pelaksanaan

Dalam pelaksanaan program kerja humas pendukung keberhasilan program Humas melibatkan keterkibatan dari seluruh elemen pendukung diantaranya kepala sekolah selaku penanggung jawab, guru dan siswa. Pelaksanaan merupakan suatu tindakan yang nyata bagi humas dalam hal mempromosikan sekolah agar dapat terlaksana sesuai dengan perencanaan yang telah ditetapkan secara efektif dan efisien. Strategi ini digunakan humas untuk memperkenalkan bagaimana Sekolah MTs Pacet ini dalam hal menarik minat masyarakat luas bukan hanya yang ada 
dilingkup Pacet saja tetapi diluar lingkup Pacet bisa melihat bagaimana MTs Pacet ini. Dalam akun facebook dimana seluruh kegiatan-kegiatan yang ada di MTs Pacet ini dimuat di dalam akun tersebut.

Selain mengunakan metode langsung dan tidak langsung MTs Pacet juga menggunakan strategi pencitraan. Dimana strategi ini digunakan dalam upaya menciptakan citra positif dilingkungan masyarakat dan program yang dijalankan dapat menimbulkan kesan yang baik dimata masyarakat.

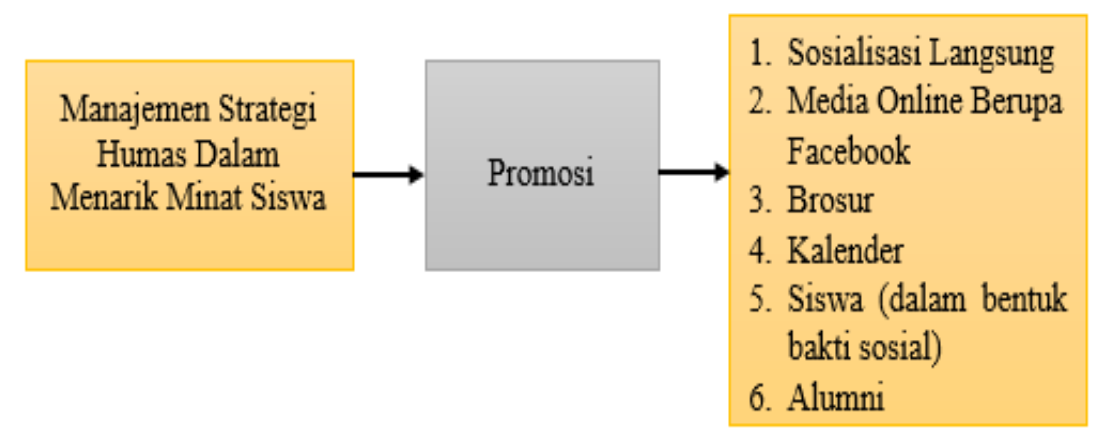

d. Pengevaluasian

Evaluasi perlu dilakukan untuk mengetahui sejauh mana keberhasilan dan hambatan apa saja yang dialami selama kegiatan berlangsung. Berdasarkan hasil penelitian, dimana peneliti menemukan bahwa evaluasi manajemen strategi Humas di MTs Pacet ini dilakukan setelah program-program kerja humas dilaksanakan. Evaluasi Humas di MTs Pacet ini bertujuan untuk melihat tingkat keberhasilan dari program kerja yang telah dilaksanakan.

2. Faktor Penghambat Manajemen Strategi Hubungan Masyarakat

Dari hasil penelitian yang diperoleh di lapangan ada beberapa faktor penyebab penghambat manajemen strategi Humas yang menyebabkan menurunya minat siswa bersekolah di MTs Pacet. Sebagaimana hal tersebut terdapat di dalam teori yang dikemukakan Rowe mengenai manajemen strategi yang terdapat peluang dan ancaman yang ada di dalammnya. Faktor tersebut meliputi: waktu, jarak lokasi dan banyaknya sekolah baru yang mulai beroperasi. 
a. Waktu

Dalam menjalankan program pelaksanaan, humas harus bisa mengalokasikan waktu yang sesuai agar pelaksanaan dapat berjalan dengan baik. Berdasarkan dari hasil penelitian yang peneliti temukan di MTs Pacet waktu pelaksanaan program kerja humas dalam mempromosikan sekolah hanya pada waktu memasuki tahun ajaran baru saja. Kendala yang dihadapi humas pada saat pelaksanaan program kerja yaitu siswa dan guru. Dimana saat sosialisasi ke sekolah humas melibatkan guru dan siswa di Sekolah MTs untuk membantu proses sosialisasi ke lembaga Sekolah SD dan MI agar program sekolah dapat terlaksana dan tersampaikan sesuai dengan harapan.

Pada saat proses sosialisasi berlangsung, dimana siswa dan guru yang terlibat dalam sosialisasi ke lembaga Sekolah SD dan MI harus meninggalkan jam pelajaran di kelas. Hal ini tentunya dianggap sebagai suatu kendala bagi sekolah dikarenakan pada saat sosialisasi menggunakan waktu siswa di sekolah.

b. Jarak lokasi

Selain waktu faktor penghambat manajemen strategi humas yaitu mengenai jarak lokasi sekolah SD dan MI. Dimana berdasarkan dari hasil penelitian Humas di MTs Pacet ini hanya mensosialisasikan program sekolah ke lembaga-lembaga SD dan MI yang terdekat saja. Hal ini disebabkan karena perhitungan waktu dan biaya dan ratarata siswa-siswi yang masuk ke Sekolah MTs ini hanya mereka yang memiliki jarak rumah yang dekat dengan Sekolah MTs ini saja. Sehingga untuk Sekolah SD dan Mi yang jaraknya jauh dari Sekolah MTs Pacet ini tidak pernah mensosialisasikannya secara langsung.

\section{KESIMPULAN}

Berdasarkan uraian paparan informasi data di atas dan dari hasil temuan penelitian serta pembahasan maka peneliti menarik beberapa kesimpulan untuk menjawab setiap fokus dan tujuan dari penelitian. Kesimpulan ini untuk mengetahui manajemen strategi Humas di MTs Pacet. Hasil kesimpulan yang dapat peneliti tarik adalah sebagai berikut: 
1. Manajemen strategi yang dilakukan oleh Humas di Yayasan Surban MTs Pacet dalam meningkatkan minat siswa antara lain:

a. Melakukan sosialisasi langsung kesekolah-sekolah SD dan MI, dengan mendatangkan guru dan perwakilan siswa-siswi MTs Pacet.

b. Melakukan promosi sekolah melalui media online berupa facebook.

c. Melakukan promosi sekolah melalui media cetak berupa brosur dan kalender

d. Melakukan Promosi melalui siswa, guru dan alumni MTs Pacet.

Sebelum melakukukan promosi sekolah kepada siswa selaku sasarannya dimana Humas di MTs Pacet terlebih dahulu melakukan Perencanaan dengan sistem rapat, Pengkomunikasian dengan pihak sekolah dan luar sekolah yang dijalin dengan baik, Pelaksanaan yang melibatkan siswa dan guru yang ada di sekolah dan Evaluasi yang dilaksanakan sertiap akhir dari kegiatan.

Adapun faktor penghambat manajemen strategi Humas dalam meningkatkan minat siswa, yaitu: faktor waktu, jarak lokasi dan banyaknya sekolah baru yang didirikan/beroperasi sebagai kompetetor.

Selain faktor penghabat, terdapat juga faktor pendukung di dalamnya. Dimana dalam pelaksanaan manajemen strategi humas sekolah harus mendukung penuh setiap kegiatan yang akan dilaksanakan. Humas di MTs Pacet mendapat dukungan penuh dari sekolah seperti biaya operasional selama proses sosialisasi berlangsung serta peralatan dan media yang dibutuhkan oleh humas selama proses sosialisasi dan promosi berlangsung.

\section{DAFTAR PUSTAKA}

Rachmad, Manajemen Strategik, (Bandung: CV Pustaka Setia, 2014)

Sugiyono, Metode Penelitian Pendidikan Pendekatan Kualitatif, Kuantitatif dan $R \& D$, (Bandung: Alfabeta, 2007)

Irawan Soehartono, Metode Penelitian Sosial, (Bandung: Remaja Rosdakarya, 1999)

Akdon, Strategic Management For Educational Management (Manajemen Strategic Untuk Manajemen Pendidikan), (Alfabeta: Bandung, 2006) 
Yosal Iriantara, Manajemen Strategis Public Relations, (Jakarta: Ghalia Indonesia, 2004)

Yuke Rahmawati, "Manajemen Public Relations Sebagai Alat Etika Komunikasi dalam Bisnis Islam”, Salam; Jurnal Filsafat dan Budaya Hukum - 183

Lilis Yulianti, Jurnal Walisongo (Faktor-Faktor Yang Mempengaruhi Minat Masyarakat), Volume 19, Nomor 1, Mey 2011, 110

Raminah Barbirin, Teori dan Apresiasi Puisi (Semarang: IKIP Semarang Pres, 1990)

Ujang Didi Supriyadi, Jurnal Ilmu Pendidikan (Pelaksanaan BOS dan Minat Masyarakat Mengikuti Pendidikan Dasar Gratis. Jilid 7. Nomor 1, Februari 200, 80.

Shaleh Abdul Rahman, Muhbibi Abdul Wahab, Psikologi Suatu Pengantar (Dalam Prespektif Islam), (Jakarta: Prenada Media, 2004)

Abdul Rahmad, Manajemen Humas Sekolah, (Yogyakarta: Media Akademi, 2016)

Rachmadi, Public Relations, (Jakarta: PT Gramedia Pustaka Utama, 1996)

Uraian Tugas Pokok Tenaga Administrasi (Berdasarkan Permen Diknas RI No. 24 Tahun 2008 Tentang Standart Tenaga Adminstrasi Sekolah).

Rosalina Nurizal Andi, Manajemen Hubungan Masyarakat dalam Menarik Minat Masyarakat di SMK 2 Ponorogo "Tesis", (Universitas Islam Negeri Maulana Malikibrahim: Malang), 40.

Anwar Yahya, Upaya Sekolah dalam Meningkatkan Animo Siswa Bersekolah di SMK Perkebunan MM 52 Yogyakarta (Tesis), 28.

Ira Nur Harini, "Manajemen Hubungan Masyarakat dalam Upaya Peningkatan Pencitraan Sekolah (Studi Kasus di SMP Al-Hikmah Surabaya)", Jurnal Inspirasi Manajemen Pendidikan, Vol. 4 No. 4, April 2014, 12. 